\title{
MATHEMATICAL QUESTIONING ABILITY OF JUNIOR HIGH SCHOOL STUDENTS
}

\author{
Xiangjie Zhang \\ Guangxi Normal University, China \\ Email: 949221694@qq.com \\ Hailun Fu \\ Shandong Normal University, China \\ Email: 949221694@qq.com
}

DOI: 10.35445/alishlah.v12.i2.277

Accepted: November $23^{\text {rd }}, 2020$. Approved: December $11^{\text {th }}, 2020$

Published: December 30 $0^{\text {th }}, 2020$

\begin{abstract}
This study aims to investigate students' mathematical questioning ability in junior high school students. The new phase of curriculum reform in China requires cultivating students 'innovative enthusiasm and practical abilities to some extent, the development of students' innovative abilities, which are prominently manifested in student inquiry learning. One of which is students' ability to ask questions. This research uses quantitative methods. Data collection was carried out using a questionnaire. A questionnaire to 80 junior high school students studied mathematics, and the reasons for the learning questions were analyzed. Data were taken in 2018 and 2019. Describe the motivation and resilience of junior high school students' math questioning abilities. They are trying to find ways to effectively improve junior high school students' math questioning skills. This study indicates that the frequency of asking students is still low, students still believe that the teacher is always right and never deny that the teacher teaches what is wrong. In further research, further research can be carried out on how to increase the frequency of student questions in teaching and learning activities.
\end{abstract}

Keywords: Junior High School Students, Mathematical Questioning, Curriculum

Reform in China

\section{KEMAMPUAN BERTANYA MATEMATIS SISWA DI SEKOLAH MENENGAH PERTAMA}

\begin{abstract}
Abstrak
Penelitian ini bertujuan untuk mengetahui kemampuan bertanya matematis siswa pada siswa sekolah menengah pertama. Babak baru reformasi kurikulum membutuhkan penanaman semangat inovatif siswa dan kemampuan praktis,
\end{abstract}


Al-Ishlah: Jurnal Pendidikan - ISSN: 2087-949o (p); 2597-940X (e)

Vol. 12 , No. 2 (2020)

sampai batas tertentu, pengembangan kemampuan inovatif siswa, yang secara mencolok terwujud dalam pembelajaran bertanya siswa. Salah satunya adalah kemampuan siswa untuk bertanya. Penelitian ini menggunakan metode kuantitatif. Pengumpulan data dilakukan dengan menggunakan kuesioner. Dari kuesioner dianalisis alasan dan kemampuan bertanya siswa di sekolah menengah pertama. Kuesioner menggambarkan motivasi dan ketahanan kemampuan bertanya matematika siswa sekolah menengah pertama. Mencoba mencari cara untuk secara efektif meningkatkan kemampuan bertanya matematika siswa sekolah menengah pertama. hasil pada penelitian ini menunjukkan bahwa frekuensi bertanya siswa masih rendah, siswa masih percaya bahwa guru selalu benar, dan tidak pernah menyangkal jika guru mengajarkan yang salah.

Kata Kunci: Siswa SMP, Kemampuan Bertanya, Reformasi Kurikulum China

\section{INTRODUCTION}

When teaching and learning activities, teachers are always asking questions to students. Questions that are given to students can be in the form of oral or written, either in the form of practice questions, test questions, or homework. So that teachers know the condition of students and the level of students' understanding of mathematics material. Furthermore, only a few studies have analyzed students' ability to ask questions and is there a relationship about increasing students' mathematical abilities with the number of students asking questions.

Meanwhile, when students ask questions, it will stimulate student interest in learning mathematics. Through question and answer, the teacher can measure the extent to which students understand a material and whether students have mastered mathematics material well. Asking questions can also improve students' critical and creative thinking. Furthermore, questions can also increase students' confidence. Of course the teacher must bring a supportive learning atmosphere, not make students tense, so that students get a comfortable atmosphere in the classroom. This learning atmosphere can be achieved by using learning models or the use of technology in the classroom (Hermita et al., 2020; Hutajulu, Wijaya, \& Hidayat, 2019; T.T. Wijaya, Jianlan, \& Aditya, 2020; Tommy Tanu Wijaya, Ying, Chotimah, \& Bernard, 2020; L. Zhang, Zhou, \& Wijaya, 2020).

In mathematics class, teachers may be confused about using good instructional media or learning models (Koh, Woo, \& Lim, 2013; Listiawan, Purwanto, As' Ari, \& Muksar, 2018; Psycharis \& Kalogeria, 2018). students spend much time listening to the explanation of the material that the teacher provides (Aditya, Wijaya, Dewi, \& Zulfah, 2020; Büyükdede \& Tanel, 2019; Hamzah, Ariffin, \& Hamid, 2017; T T Wijaya et al., 2020; X. Zhang, Zhou, \& Wijaya, 2020). These activities make students lack interaction and opportunities to ask 
Al-Ishlah: Jurnal Pendidikan - ISSN: 2087-949o (p); 2597-940X (e)

Vol. 12 , No. 2 (2020)

questions. So that, the teacher may not know the level of understanding of the students.

Studying mathematics is closely related to everyday life (Wijaya, 2021). Students' thinking needs to be stimulated and challenged to make students interested in mathematics. one of them is by training students with Olympic questions (Jatmiko, Fatahillah, Oktavianingtyas, \& Rochmah, 2020; Manfrino, 2015; Shoho, 1996). If students do not understand, they will look for teachers to solve the Olympics questions.

Teachers should be able to use technology to stimulate students to ask questions (Hernawati \& Jailani, 2019). Teachers must be good at developing questions and learning models that increase student interest in learning. for example, teachers can relate lessons to problems in the real world (Fitri \& Prahmana, 2019; Wijaya \& Afrilianto, 2018) if the student interest is good. Involve students and challenge them to solve problems (Hidayat \& Sariningsih, 2018; Rohaeti, Nurjaman, Sari, Bernard, \& Hidayat, 2019; Tezer \& Karasel, 2010). then students will take the initiative to ask questions and be active in participating in teaching and learning activities in class.

Questioning mathematics learning is problem-based learning (Andini, Mulyani, Wijaya, \& Supriyati, 2018; Bernard, Sumarna, Rolina, \& Akbar, 2019; T.T. Wijaya, Dewi, Fauziah, \& Afrilianto, 2018), knowledge as the carrier (Agyei, 2019; Yeh, Cheng, Chen, Liao, \& Chan, 2019), thinking as the soul, and questioning as the characteristic. It is a learning method that promotes students to learn to learn (Aixia, Ying, \& Wijaya, 2020; Fitri \& Prahmana, 2018), solve doubts, and experience the joy of success. With the progress of a new round of curriculum reform, traditional teaching methods have encountered unprecedented resistance in cultivating students' "spirit of innovation and practical ability". Therefore, "questioning", which can enhance the critical spirit of students' creative ability, plays an increasingly prominent role in mathematics learning. Considering the questioning ability of junior high school mathematics as an example, the relevant research is carried out on the current situation of junior high school students' mathematical questioning to find ways to effectively improve the mathematical questioning ability of junior high school students.

Through the online and offline literature review, understand the current status of the research on junior high school mathematics (H. Hendriana, Eti Rohaeti, \& Hidayat, 2017). the teaching of cultivating the questioning ability and how to train the student's questioning ability as the reference direction (Heris Hendriana, Rohaeti, \& Hidayat, 2017), learn from the research methods and theoretical results, and form the relevant questioning Investigation and research of learning ability. 
Al-Ishlah: Jurnal Pendidikan - ISSN: 2087-949o (p); 2597-940X (e)

Vol. 12 , No. 2 (2020)

\section{METHOD}

This research using a quantitative method, combining and studying the relevant literature on the current situation of mathematical questioning of junior high school students, two parallel classes of the first grade in a junior high school were randomly selected for investigation, of which there were 40 students in each class with total 80 students. Firstly, students' questionnaires are distributed to understand the current situation of junior high school students' mathematical questioning. 80 questionnaires were distributed and 80 were returned, with a recovery rate of $100 \%$. After screening 80 questionnaires, the remaining 76 were 95\% effective. Then conduct interviews with relevant teachers, investigate and understand the current situation of junior high school students' mathematical questioning from the perspective of teachers, and provide additional evidence for the results of students' questionnaires. Finally, perform SPSS data analysis on related questionnaires, explain the results and give suggestions.

By handling out questionnaires in junior high schools' actual classrooms, we can understand the students' learning situation. In the classification and sorting of different problems, we can form an understanding of the three aspects of questioning learning ability and ask the next step to analyze the data. While compiling the questionnaire, the corresponding interview outline is formed, the teachers are interviewed, and the three aspects of the students' questioning learning ability are understood through the investigation of the teachers and the teacher's encounters in cultivating students' questioning learning ability. Problems or resistance. From the questioning teaching, pry into the current situation of questioning learning, understand the biggest problems of current questioning learning, and the progress of the cultivation of junior high school students' math questioning learning ability.

\section{FINDINGS AND DISCUSSION}

\section{Finding}

First, use principal component analysis to reduce the dimensionality of the data. A set of variables is represented by one variable, and then the correlation analysis between the two sets of variables is simplified to the correlation analysis between the two variabel.

The correlation analysis of the first group of questions is good, so the principal component analysis is performed to reduce the dimensionality, and the six questions of the first group are extracted into a variable $\mathrm{X}$, and then the three aspects are analyzed. 
Al-Ishlah: Jurnal Pendidikan - ISSN: 2087-949o (p); 2597-940X (e)

Vol. 12 , No. 2 (2020)

Table 1 Main Component Analysis Factor X

\begin{tabular}{ccccccc}
\hline \multicolumn{6}{c}{ Total stated variance } \\
\hline & \multicolumn{5}{c}{ Starting eigenvalue } & \multicolumn{3}{c}{ Extract the sum of squares and load } \\
\cline { 2 - 7 } No & Total & Difference \% & Cumulative \% & Total & Difference \% & Cumulative \% \\
\hline 1 & 2.689 & 44.809 & 44.809 & 2.689 & 44.809 & 44.809 \\
2 & 1.068 & 17.803 & 62.612 & 1.068 & 17.803 & 62.612 \\
3 & .897 & 14.950 & 77.562 & & & \\
4 & .558 & 9.303 & 86.865 & & & \\
5 & .490 & 8.165 & 95.030 & & & \\
6 & .298 & 4.970 & 100.000 & & \\
\end{tabular}

Acquisition method: a main component analysis.

Table 1 shows: the first group has six components (six questions). Generally speaking, the first principal component of the result output contains the most data variation. The variation of the initial feature value represents the degree of data variation, and the cumulative amount is the above. The cumulative variance of each component. There are two items in the extracted sum of squares and load, indicating that components 1 and 2 are the extracted principal components, and then the common factor $\mathrm{X}$ is obtained after processing components 1 and 2 .

Table 2 Main Component Analysis factor $Y$

\begin{tabular}{|c|c|c|c|c|}
\hline \multicolumn{5}{|c|}{ Total stated variance } \\
\hline \multirow[b]{2}{*}{ No } & \multicolumn{3}{|c|}{ Starting eigenvalue } & Extract the sum of squares and load \\
\hline & Total & Difference \% & Cumulative \% Total & Difference \% Cumulative \% \\
\hline 1 & 1.820 & 45.504 & 45.504 & 45.504 \\
\hline 2 & .985 & 24.613 & 70.117 & \\
\hline 3 & .727 & 18.163 & 88.281 & \\
\hline 4 & .469 & 11.719 & 100.000 & \\
\hline
\end{tabular}

Acquisition method: analysis of main components.

Table 2 shows: The first group has four components (four questions). There is an item in the extraction of the sum of squares and loading, indicating that component 1 is the principal component of the extraction, and the familiar factor $\mathrm{Y}$ is obtained. 
Al-Ishlah: Jurnal Pendidikan - ISSN: 2087-949o (p); 2597-940X (e)

Vol. 12 , No. 2 (2020)

Table 3 Main Component Analysis Factor $\mathbf{Z}$

\begin{tabular}{rrrrrrr}
\hline & \multicolumn{2}{c}{ Starting eigenvalue } & \multicolumn{2}{c}{$\begin{array}{c}\text { Extract the sum of squares and } \\
\text { load }\end{array}$} \\
\cline { 2 - 7 } No & \multicolumn{1}{c}{ Total } & Variation & \multicolumn{1}{c}{$\begin{array}{c}\text { Cumulative } \\
\text { \% }\end{array}$} & Total & Variation & $\begin{array}{c}\text { Cumulative } \\
\%\end{array}$ \\
\hline 1 & 1.511 & 50.375 & 50.375 & 1.511 & 50.375 & 50.375 \\
2 & .941 & 31.374 & 81.749 & & & \\
3 & .548 & 18.251 & 100.000 & & & \\
& & & & & & \\
\hline
\end{tabular}

Acquisition method: main component analysis.

Table 3 shows that the first group has three components (three questions). There is an item in the extraction of the squares loading, indicating that component 1 is the principal component of the extraction, and the standard factor $\mathrm{Z}$ is obtained. Pearson correlation test is performed on the three new variables $\mathrm{X}$, $\mathrm{Y}$, and $\mathrm{Z}$ obtained by the extraction of principal components, and Table 4 is obtained.

\section{Table 4 Correlation Test using Pearson}

\section{Pearson correlation test}

\begin{tabular}{lllll}
\hline & & $\mathrm{X}$ & \multicolumn{1}{c}{$\mathrm{Z}$} \\
\hline $\mathrm{X}$ & Pearson related & 1 & $.446^{* *}$ & $.313^{* *}$ \\
$\quad$ Significance (two-tailed) & & .000 & .006 \\
$\mathrm{~N}$ & 76 & 76 & 76 \\
\hline $\mathrm{Y} \quad$ Pearson related & $.446^{* *}$ & 1 & $.313^{* *}$ \\
& Significance (two-tailed) & .000 & & .006 \\
& $\mathrm{~N}$ & 76 & 76 & 76 \\
\hline $\mathrm{Z}$ & Pearson related & $.313^{* *}$ & $.313^{* *}$ & 1 \\
$\quad$ Significance (two-tailed) & .006 & .006 & \\
$\mathrm{~N}$ & 76 & 76 & 76 \\
\hline
\end{tabular}

$\overline{* *}$. The correlation is significant at level 0.01 (two-tailed)

Table 4 shows that the correlation coefficient between $X$ and $Y|r|=0.446$, there are two asterisks in the upper right corner, and "**" in the lower-left corner 
Al-Ishlah: Jurnal Pendidikan - ISSN: 2087-949o (p); 2597-940X (e)

Vol. 12 , No. 2 (2020)

\begin{tabular}{lcccc} 
C. occasionally & 48 & 63.2 & 63.2 & 88.2 \\
D. never & 9 & 11.8 & 11.8 & 100.0 \\
total & 76 & 100.0 & 100.0 & \\
\hline A. always & 4 & 5.3 & 5.3 & 5.3 \\
B. often & 18 & 23.7 & 23.7 & 28.9 \\
C. occasionally & 45 & 59.2 & 59.2 & 88.2 \\
D. never & 9 & 11.8 & 11.8 & 100.0 \\
total & 76 & 100.0 & 100.0 & \\
\hline Question 5. always & 10 & 13.2 & 13.2 & 13.2 \\
B. often & 46 & 60.5 & 60.5 & 73.7 \\
C. occasionally & 18 & 23.7 & 23.7 & 97.4 \\
D. never & 2 & 2.6 & 2.6 & 100.0 \\
total & 76 & 100.0 & 100.0 & \\
\hline Question 12A. always & 14 & 18.4 & 18.4 & 18.4 \\
B. often & 46 & 60.5 & 60.5 & 78.9 \\
C. occasionally & 15 & 19.7 & 19.7 & 98.7 \\
D. never & 1 & 1.3 & 1.3 & 100.0 \\
total & 76 & 100.0 & 100.0 & \\
\hline Question 13A. always & 9 & 11.8 & 11.8 & 11.8 \\
B. often & 42 & 55.3 & 55.3 & 67.1 \\
C. occasionally & 24 & 31.6 & 31.6 & 98.7 \\
D. never & 1 & 1.3 & 1.3 & 100.0 \\
total & 76 & 100.0 & 100.0 & \\
\hline
\end{tabular}

For students themselves, students are eager for teachers to entrust the classroom to themselves, and most also think teachers must ask themselves questions. But there is no precise definition of what should be asked in class and what question is the most valuable. Students believe that teachers' over-control of the classroom is not conducive to their own learning. But in terms of homework, the answer is generally correct, and you will not think further about other things. May occasionally question the known knowledge or seek other methods. It shows that junior high school students have a preliminary understanding of mathematical questioning, but there is no practical way to guide this idea of controlling the classroom by themselves to become further questionable.

Question 2. Any point raised by the teacher must be correct

Question 6. In math learning, can you ask questions that other students did not think of?

Question 9. Can you object to the teacher's classroom teaching and the opinions of the classmates?

Question 10. Can you continue to follow up on the questions of the math teacher or classmates? 
Al-Ishlah: Jurnal Pendidikan - ISSN: 2087-949o (p); 2597-940X (e)

Vol. 12 , No. 2 (2020)

Table 6 The Results of the Questionnaire about Students' Attitudes if the Teacher Taught the Questions Incorrectly

\begin{tabular}{|c|c|c|c|c|c|}
\hline \multicolumn{2}{|c|}{ Question and Answer } & Total & $\%$ & Effective \% & $\begin{array}{c}\text { Cumulative } \\
\%\end{array}$ \\
\hline \multirow{4}{*}{ Question 2} & A yes & 7 & 9.2 & 9.2 & 9.2 \\
\hline & B no & 66 & 86.8 & 86.8 & 96.1 \\
\hline & $\begin{array}{l}\mathrm{C} \text { didn't think about this } \\
\text { problem }\end{array}$ & 3 & 3.9 & 3.9 & \multirow[t]{2}{*}{100.0} \\
\hline & total & 76 & 100.0 & 100.0 & \\
\hline \multirow{5}{*}{ Question 6} & A. always & 4 & 5.3 & 5.3 & 5.3 \\
\hline & B. often & 8 & 10.5 & 10.5 & 15.8 \\
\hline & C. occasionally & 51 & 67.1 & 67.1 & 82.9 \\
\hline & D. never & 13 & 17.1 & 17.1 & 100.0 \\
\hline & total & 76 & 100.0 & 100.0 & \\
\hline \multirow{5}{*}{ Question 9} & A often can & 10 & 13.2 & 13.2 & 13.2 \\
\hline & B occasionally & 46 & 60.5 & 60.5 & 73.7 \\
\hline & $\mathrm{C}$ basically cannot & 19 & 25.0 & 25.0 & 98.7 \\
\hline & $\mathrm{D}$ can't at all & 1 & 1.3 & 1.3 & 100.0 \\
\hline & total & 76 & 100.0 & 100.0 & \\
\hline \multirow{5}{*}{ Question 10} & A often can & 10 & 13.2 & 13.2 & 13.2 \\
\hline & B occasionally & 43 & 56.6 & 56.6 & 69.7 \\
\hline & $\mathrm{C}$ basically cannot & 22 & 28.9 & 28.9 & 98.7 \\
\hline & D can't at all & 1 & 1.3 & 1.3 & 100.0 \\
\hline & total & 76 & 100.0 & 100.0 & \\
\hline
\end{tabular}

Junior high school students have the initial ability to question the knowledge that teachers say, but many students have the impression of the authority of teachers' knowledge, and they have never even thought that teachers will make mistakes. However, compared with the questioning of students' answers, especially the answers of students with better grades), the ability to ask questions is even more lacking.

Question 1. The content on the textbook or materials must be correct

Question 7. In the learning mathematics textbook, can you ask questions or different opinions?

Question 8. Can you find errors in mathematics textbooks and test papers 
Al-Ishlah: Jurnal Pendidikan - ISSN: 2087-949o (p); 2597-940X (e)

Vol. 12 , No. 2 (2020)

Table 7 The Results of the Questionnaire about Students' Attitudes if there are Questions that are Wrong in the Textbook

\begin{tabular}{llllll}
\hline \multicolumn{1}{c}{ Question and Answer } & \multicolumn{2}{c}{ total } & \multicolumn{2}{c}{ Effective $\begin{array}{c}\text { Cumulative } \\
\text { \% }\end{array}$} \\
\hline Question 1 & A is & 11 & 14.5 & 14.5 & 14.5 \\
& B is not & 55 & 72.4 & 72.4 & 86.8 \\
& $\begin{array}{l}\text { C never thought about this } \\
\text { problem }\end{array}$ & 10 & 13.2 & 13.2 & 100.0 \\
& total & 76 & 100.0 & 100.0 & \\
\hline Question 7 & A often can & 2 & 2.6 & 2.6 & 2.6 \\
& B occasionally & 46 & 60.5 & 60.5 & 63.2 \\
& C basically cannot & 26 & 34.2 & 34.2 & 97.4 \\
& D can't at all & 2 & 2.6 & 2.6 & 100.0 \\
& total & 76 & 100.0 & 100.0 & \\
\hline Question 8 often can & 3 & 3.9 & 3.9 & 3.9 \\
B occasionally & 49 & 64.5 & 64.5 & 68.4 \\
C basically cannot & 18 & 23.7 & 23.7 & 92.1 \\
D can't at all & 6 & 7.9 & 7.9 & 100.0 \\
total & 76 & 100.0 & 100.0 & \\
\hline \hline
\end{tabular}

Compared with doubts about teachers, there are relatively few questions about teaching materials and learning materials. They think that the textbook is a "theorem", and only about half of the students occasionally put forward different opinions and point out errors in the textbook.

According to the three levels of the problem, we still analyze the status quo causes from the three levels. Then separate the psychological mechanism from the student's own perspective, focusing on summing up the current problems from the student's own perspective and trying to find the most appropriate improvement measures.

\section{Discussion}

The identity of "passive acceptance": teaching, teachers teach students to learn. Students' own perception of teaching is a one-way arrow from "from 
Vol. 12 , No. 2 (2020)

teacher to student". What the teacher said must be right and what is written in the textbook must be the best. I have never even thought that there will be errors in the teacher's textbook and rely on the teacher to rely on the textbook to the point where it should be.

Time, energy and tasks: from junior high school, teaching tasks have been aggravated. In addition to mathematics students, there are many homework (especially mathematics is still a difficult subject, the quality of homework is high, and the quantity is large). The teacher's answering method, the students who don't study will not even complete the homework. There is no time and energy to think about whether the method is correct, whether there are other answers to the questions that have already been answered. Some students told me that they only looked at the results for the answers. Even when they knew that some students had different methods of solving problems independently, as long as the results were correct, they would not want to learn about other methods.

Personal ability: Students with poor foundations cannot conduct questioning learning. Mental mechanism dependence on teachers, teaching materials, etc.: The psychology of dependence causes behaviors similar to laziness in learning, that is, lack of ability to question. Use established theoretical methods without thinking about it. Maybe this kind of dependence is only the dependence on others' help in the "support teaching", but if the support is not gradually withdrawn, students cannot learn to think about their own growth.

Significance of learning: Most junior high school students still think that learning is for their parents and teachers. They cannot find the meaning and fun of learning from the learning itself. If they think that learning is a task that can be completed, it will not invest a lot of energy Time to delve into it.

The motivation for learning: the external motivation of junior high school students is stronger than the internal motivation, the praise of teachers and parents, the "vanity" brought by excellent grades, these are more joy than answering questions, and even too many external motivations weaken internal motivation.

Interest: Interest is the best teacher. Excessively depressive or boring classrooms confine junior high school students' imagination and deprive them of doubting ideas and courage. A student told me that the math teacher she likes will make her like learning mathematics and give her more space instead of always teaching in class and lack of interaction.

A large number of indirect knowledge systems: civilization has continued to this day. To master a large amount of system knowledge in a short time, the class teaching system has always been the best way to teach. The indirectness and complexity of the cultural system, in order to stand on giants' shoulders, we have to think by the ideas of giants. 
Al-Ishlah: Jurnal Pendidikan - ISSN: 2087-949o (p); 2597-940X (e)

Vol. 12 , No. 2 (2020)

Authoritative learning atmosphere: the authority of parents and teachers have allowed students to learn to be "obedient", "correct answer" and "only answer", which wiped out their curiosity and questioning spirit.

Exam-oriented education: Under the requirement of examination-oriented education to pay attention to results and examinations, schools or teachers will inevitably pay too much attention to students' examination results (results). Ignore the student body and ignore the process.

\section{CONCLUSION}

Based on the above data analysis and display, the current situation of junior high school students' questioning learning in mathematics is not ideal. It shows that 1). junior high school students have a preliminary understanding of questioning learning in mathematics, but there is no practical way to guide this idea of controlling the classroom. Become the ability to question. 2). junior high school students have the initial ability to question teachers' knowledge, but there are still many students who have the impression of the authority of teachers' knowledge, and they have never even thought that teachers will make mistakes 3). Questions about textbooks and learning materials are relatively rare. They think that the textbook is a "theorem", and only about half of the students occasionally put forward different opinions and point out that the textbook is not ideal in three areas.

\section{REFERENCES}

Aditya, P., Wijaya, T. T., Dewi, S. N., \& Zulfah, Z. (2020). analisis buku siswa matematika sma dari indonesia dan china pada materi peluang dan statistik. Jurnal Cendekia: Jurnal Pendidikan Matematika, 4(2), 813-822.

Agyei, D. D. (2019). From needs analysis to large-scale implementation: Using collaborative design to support ict integration. Collaborative Curriculum Design for Sustainable Innovation and Teacher Learning, 305-328. https://doi.org/10.1007/978-3-030-20062-6_17

Aixia, W., Ying, Z., \& Wijaya, T. T. (2020). The current situation and prospect of study quality evaluation research in china in the last 10 years. EDUKATIF: JURNAL ILMU PENDIDIKAN, 2(1), 101-112.

Andini, D., Mulyani, N., Wijaya, T., \& Supriyati, D. (2018). Meningkatkan Kemampuan Komunikasi Matematis Dan Self Confidence Siswa Menggunakan Pendekatan PBL Berbantuan Geogebra. Jurnal Derivat: Jurnal Matematika Dan Pendidikan Matematika, 5(1), 82-93.

Bernard, M., Sumarna, A., Rolina, R., \& Akbar, P. (2019). Development of high 
Al-Ishlah: Jurnal Pendidikan - ISSN: 2087-949o (p); 2597-940X (e)

Vol. 12 , No. 2 (2020)

school student work sheets using VBA for microsoft word trigonometry materials. Journal of Physics: Conference Series, 1315(1). https://doi.org/10.1088/1742-6596/1315/1/012031

Büyükdede, M., \& Tanel, R. (2019). Effect of the stem activities related to workenergy topics on academic achievement and prospective teachers' opinions on stem activities. Journal of Baltic Science Education, 18(4), 507-518. https://doi.org/10.33225/jbse/19.18.507

Fitri, N. L., \& Prahmana, R. C. I. (2018). Pembelajaran Luas Segiempat untuk Siswa Kelas VII Menggunakan Reallotment Activities. Jurnal Review Pembelajaran Matematika, 3(1), 18-28. https://doi.org/10.15642/jrpm.2018.3.1.18-28

Fitri, N. L., \& Prahmana, R. C. I. (2019). Misconception in fraction for seventhgrade students. Journal of Physics: Conference Series, 1188(1). https://doi.org/10.1088/1742-6596/1188/1/012031

Hamzah, N., Ariffin, A., \& Hamid, H. (2017). Web-Based Learning Environment Based on Students' Needs. IOP Conference Series: Materials Science and Engineering, 226(1). https://doi.org/10.1088/1757-899X/226/1/012196

Hendriana, H., Eti Rohaeti, E., \& Hidayat, W. (2017). Metaphorical thinking learning and junior high school teachers' mathematical questioning ability. Journal on Mathematics Education, 8(1), 55-64. https://doi.org/https://doi.org/10.22342/jme.8.1.3614.55-64

Hendriana, Heris, Rohaeti, E. E., \& Hidayat, W. (2017). Junior high school teachers' mathematical questioning ability and metaphorical thinking learning. Journal on Mathematics Education. https://doi.org/https://doi.org/10.22342/jme.8.1.3614.55-64

Hermita, N., Ningsih, H. S., Alim, J. A., Alpusari, M., Putra, Z. H., \& Wijaya, T. T. (2020). Developing Science Comics for Elementary School Students on Animal Diversity. Solid State Technology, 63(1s).

Hernawati, K., \& Jailani. (2019). Mathematics mobile learning with TPACK framework. Journal of Physics: Conference Series, 1321(2). https://doi.org/10.1088/1742-6596/1321/2/022126

Hidayat, W., \& Sariningsih, R. (2018). Kemampuan Pemecahan Masalah Matematis dan Adversity Quotient Siswa SMP Melalui Pembelajaran Open Ended. JNPM (Jurnal Nasional Pendidikan Matematika), 2(1), 109. https://doi.org/10.33603/jnpm.v2i1.1027

Hutajulu, M., Wijaya, T. T., \& Hidayat, W. (2019). the Effect of Mathematical 
Al-Ishlah: Jurnal Pendidikan - ISSN: 2087-949o (p); 2597-940X (e)

Vol. 12 , No. 2 (2020)

Disposition and Learning Motivation on Problem Solving: an Analysis. Infinity Journal, 8(2), 229. https://doi.org/10.22460/infinity.v8i2.p229-238

Jatmiko, D. D. H., Fatahillah, A., Oktavianingtyas, E., \& Rochmah, O. A. (2020). An analysis of olympiad students' critical thinking in solving National Science Olympiad (OSN) problem on number theory material. Journal of Physics: Conference Series, 1563(1). https://doi.org/10.1088/17426596/1563/1/012037

Koh, J. H. L., Woo, H. L., \& Lim, W. Y. (2013). Understanding the relationship between Singapore preservice teachers' ICT course experiences and technological pedagogical content knowledge (TPACK) through ICT course evaluation. Educational Assessment, Evaluation and Accountability, 25(4), 321-339. https://doi.org/10.1007/s11092-013-9165-y

Listiawan, T., Purwanto, P., As'Ari, A. R., \& Muksar, M. (2018). Mathematics Teachers Technological Content Knowledge (TCK) in using Dynamic Geometry Software. Journal of Physics: Conference Series, 1114(1). https://doi.org/10.1088/1742-6596/1114/1/012121

Manfrino, R. B. (2015). Topics in algebra and analysis: Preparing for the mathematical olympiad. Topics in Algebra and Analysis: Preparing for the Mathematical Olympiad, 1-311. https://doi.org/10.1007/978-3-319-11946-5

Psycharis, G., \& Kalogeria, E. (2018). Studying the process of becoming a teacher educator in technology-enhanced mathematics. Journal of Mathematics Teacher Education, 21(6), 631-660. https://doi.org/10.1007/s10857-0179371-5

Rohaeti, E. E., Nurjaman, A., Sari, I. P., Bernard, M., \& Hidayat, W. (2019). Developing didactic design in triangle and rectangular toward students mathematical creative thinking through Visual Basic for PowerPoint. Journal of Physics: Conference Series, 1157(4). https://doi.org/https://doi.org/10.1088/1742-6596/1157/4/042068

Shoho, A. R. (1996). A cross-cultural analysis of similarities and differences among math Olympiads in China, Taiwan, and the United States. International Journal of Educational Research, 25(6), 575-582. https://doi.org/10.1016/S0883-0355(97)86734-1

Tezer, M., \& Karasel, N. (2010). Attitudes of primary school 2nd and 3rd grade students towards mathematics course. Procedia - Social and Behavioral Sciences, 2(2), 5808-5812. https://doi.org/10.1016/j.sbspro.2010.03.947

Wijaya, T.T., Dewi, N. S. S., Fauziah, I. R., \& Afrilianto, M. (2018). Analisis Kemampuan Pemahaman Matematis Siswa Kelas IX Pada Materi Bangun 
Al-Ishlah: Jurnal Pendidikan - ISSN: 2087-949o (p); 2597-940X (e)

Vol. 12 , No. 2 (2020)

Ruang. UNION: Jurnal Ilmiah Pendidikan Matematika, 6(1), 19-28. https://doi.org/10.30738/.v6i1.2076

Wijaya, T.T., Jianlan, T., \& Aditya, P. (2020). Developing an Interactive Mathematical Learning Media Based on the TPACK Framework Using the Hawgent Dynamic Mathematics Software. Emerging Technologies in Computing, 318-328. https://doi.org/10.1007/978-3-030-60036-5

Wijaya, T T, Ying, Z., Chotimah, S., Bernard, M., Zulfah, \& Astuti. (2020). Hawgent dynamic mathematic software as mathematics learning media for teaching quadratic functions. Journal of Physics: Conference Series, 1592(1). https://doi.org/10.1088/1742-6596/1592/1/012079

Wijaya, Tommy Tanu. (2021). How chinese students learn mathematics during the coronavirus pandemic. International Journal of Educational Research and Innovation (IJERI), 15, 1-16. https://doi.org/https://doi.org/10.46661/ijeri.4950

Wijaya, Tommy Tanu, \& Afrilianto, M. (2018). KEMAMPUAN KOMUNIKASI MATEMATIS SISWA SMK. JPMI (Jurnal Pembelajaran Matematika Inovatif), 1(1), 21-28. https://doi.org/10.22460/jpmi.v1i3.219-228

Wijaya, Tommy Tanu, Ying, Z., Chotimah, S., \& Bernard, M. (2020). Hawgent dynamic mathematic software as mathematics learning media for teaching quadratic functions Hawgent dynamic mathematic software as mathematics learning media for teaching quadratic functions. https://doi.org/10.1088/1742-6596/1592/1/012079

Yeh, C. Y. C., Cheng, H. N. H., Chen, Z., Liao, C. C. Y., \& Chan, T. (2019). Enhancing achievement and interest in mathematics learning through MathIsland. Research and Practice in Technology Enhanced Learning, 14(5), 119.

Zhang, L., Zhou, Y., \& Wijaya, T. T. (2020). Hawgent dynamic mathematics software to improve problem-solving ability in teaching triangles. Journal of Physics: Conference Series, 1663(1). https://doi.org/10.1088/17426596/1663/1/012069

Zhang, X., Zhou, Y., \& Wijaya, T. T. (2020). Hawgent Dynamic Mathematics Software to Teach Line and Angle. JNPM (Jurnal Nasional Pendidikan Matematika), 4(2), 237-247. 